\title{
Climate Change and the Imagining \\ of Migration: Emerging Discourses \\ on Kiribati's Land Purchase in Fiji
}

\section{Elfriede Hermann and Wolfgang Kempf}

Scientific estimates suggest that the low-lying coral atolls of the Pacific will be especially affected by climate change. The vulnerability of atoll islands and atoll states results from a specific constellation of physical, ecological, social, and economic conditions, including the lopsided relationship between small land area and lengthy coastlines, and the problems of coastal erosion, limited drinking water, high population density, paucity of economic resources, and low incomes (Barnett and Adger 2003, 322-323; Nurse and others 20I4, I623, I634; Connell 2015, I). Recent studies of the changing morphology of atolls in the western and central Pacific stress the stability that these islands have so far demonstrated in the face of rising sea levels (McLean and Kench 20I 5, 456, 458; compare Connell 20I 5, 9-I I). Still, the projected consequences of climate changesea level rise, altered precipitation regimes, an increase in extreme weather events, ocean acidification, and coral bleaching-carry considerable risks for low-lying islands, since in combination with existing environmental challenges they will exert long-term negative effects on ecosystems, coastal regions, land surfaces, settlements, freshwater supply, and food security (see, eg, Barnett 2005; Lazrus 20I2; Campbell 20I4; Nurse and others 20I4; Connell 20I5). Therefore, experts do not rule out the possibility that climate-related changes to the environment and living conditions on atoll islands will be such as to render their continued habitation impossible for the majority of those living there and, consequently, threaten the national sovereignty of atoll states (see Barnett and Adger 2003; Mimura and others 2007; Barnett and Campbell 20I0; Lazrus 2012; Nurse and others 20I4).

The Contemporary Pacific, Volume 29, Number 2, 23 I-263

(C) 2017 by University of Hawai'i Press 
For Kiribati, an atoll state of the central Pacific, the scientific, political, and media discourses conducted over the previous two decades on the likely effects of climate change have been formative (see, eg, Teuatabo 2002; MacKenzie 2004). In this context, Kiribati's government under President Anote Tong (2003-2015) undertook a series of political measures that included urgent appeals to the global community to cut greenhouse gas emission, the implementation of numerous and diverse adaptive activities, and a future-oriented migration policy. One recent step has been the acquisition of a large freehold property - an estate on Vanua Levu-in Fiji. While the government announced that the land would be used for purposes of economic development and to provide food security for Kiribati, many of the atoll state's citizens associated the purchase with the possibility of future migration to Fiji. We suggest that this future perspective points to a change in the attitudes that the I-Kiribati-the citizens of Kiribati-have long manifested toward collective migration. The previously dominant discourse had spoken of remaining on their land and in their land. That remains as true as ever. I-Kiribati continue to emphasize their strong ties to the land and their willingness to do whatever is possible to protect the land from the inroads of climate change (Kempf and Hermann 20I4, 206; Hermann 20I7). Nevertheless, with their government's purchase of land in Fiji, a new discourse seems now to have emerged, a discourse we attempt to capture in this article as the imagining of migration.

Scenarios of large-scale collective resettlement and recognition of Pacific Islanders' longing to remain are the opposite poles in today's scientific debate on climate change and migration in Oceania (Barnett and O'Neill 20I 2, 9; Lazrus 20I2, 293; Campbell and Bedford 20I4, I98). In these discussions, forced collective resettlements are seen as especially maladaptive in their end results when resettled people become landless, impoverished, and marginalized (Barnett and O'Neill 20I2, 9). This has led some researchers to favor voluntary labor migration, reasoning that this will strengthen the Islanders' long-term adaptability (Barnett and Webber 20I0, 42; Barnett and O’Neill 20I2, IO). Others are less willing to rule out careful planning for the eventuality of relocation (Campbell and Bedford 2014, 198). Central to this debate has been the argument of giving greater weight to indigenous cultural understandings of climate change impacts, adaption, contemporary mobility practices, and future migration (Farbotko and Lazrus 20I2, 382, 388). In our view, the acquisition of land negotiated between the political representatives of two neighboring 
Pacific states furnishes an ideal analytic lens through which to study indigenous discourses on remaining, belonging, and relocation.

The decision by Kiribati's government to purchase freehold land in Fiji has received some attention in the academic literature on climate change and migration. However, critical voices, such as that of a commentator from Kiribati who saw the land purchase as an instance of poorly conceived planning of development projects by the government (Korauaba $2015,233-234,236)$, have been rare in that quarter. In any case, official announcements that the rationale was purely economic were of secondary importance in the literature. Rather, the general thrust of these studies was the eventuality of I-Kiribati being relocated to Fiji, the more so as Fijian politicians held out the prospect of granting refuge to the inhabitants of neighboring atoll states like Kiribati and Tuvalu, should their islands ever be rendered uninhabitable (see Bedford and Bedford 2010, 90-92; Campbell and Bedford 20I4, I80-I8I; McAdam 2014, 302; Klepp and Herbeck 20I6, 70-7I). Writing in this connection, a team of authors-Carol Farbotko, Elaine Stratford, and Heather Lazrus (2016, 537) —saw a direct link between the land purchase and the migration policy espoused by Kiribati's government under Anote Tong, even though the entry on Kiribati's official website, which they cite as evidence thereof, does not point to such an unequivocal association. Several other authors construed the vision of a future relocation as parallel to earlier resettlement projects, mostly dating from the colonial era (Campbell and Bedford 20I4; McAdam 20I4). Yet others felt they had to interpret Kiribati's land purchase as a sign of a political gravitation toward recognition of resettlement as a solution to climate-induced displacement (Leckie 2014,34) - or even as proof of the undisputable presence of climate change impacts (Fiske and others 20I4, I3-I4). However, despite the academic interest the land purchase has attracted, there is still a scarcity of empirical data on the views of citizens in Kiribati and Fiji.

In this article, we choose to focus on the indigenous discourses and practices in the two countries. We argue that the land purchase by Kiribati's government has lent considerable impetus to the imagining of migration, not only in Kiribati but also in Fiji. As we show, these imaginings have been fostered by the climate change policies of the two Pacific states as well as by concepts of land on which their citizens rely. Tsunami warnings and flooding caused by extreme weather events have also contributed to many I-Kiribati taking projections of climate change impacts more seriously, including weighing the available options for staying on 
the land or moving elsewhere. Focusing on imaginings of migration we align ourselves with a perspective that - by reconceptualizing the idea of culture via the lens of mobility, travel, migration, and diaspora (see, eg, Clifford 1997)—attempts to incorporate not only physical but also imagined movement as a constitutive element of place, culture, and identity (see Rapport and Dawson 1998; Dawson and Johnson 2001). The social relevance of imagination has been accorded an even broader reception in the field of migration studies. Accordingly, imagination-or more exactly, acts of imagination or imaginings-was said to characterize the agency of actors in a framework of mobility, migration, and transnational links. Moreover, while imaginings of movement, migration, and global spaces were seen to impact on locality, place, and dwelling, visions of homeland and permanence were also enlisted as shaping factors behind mobility, migration, and diaspora (see Appadurai I996, 3 I, 5 5-56; 200I, 6-7; Pessar and Mahler 2003, 8I7-8I 8; Salazar 20II, 577, 586-587).

Arjun Appadurai has emphasized the influence wielded by mass media images and narratives on the life choices of ordinary people. Initially he focused on the role played by imaginings in such matters as locality, social praxis, and individual agency (see Appadurai 1996, 200I). In a further step, Appadurai combined the idea of imagination with those of aspiration and anticipation (2013). On the basis of this triangulation he advanced his concept of the future as a cultural configuration. He sought this process of culturally constructing the future in the contrasting terrain of everyday practices and a politics of imagination, hope, and risk assessment on the one hand, and a modern regime of numbers, calculation, and probability endemic to capitalist speculation and profit generation on the other (Appadurai 2013, 286-298).

In what follows, the focus is on imagination in relation to aspiration and anticipation. We place this configuration in direct connection with the idea of potential threats posed by human-induced climate change. We speak of anticipation (in the sense of Appadurai's regime of numbers and probabilities) especially when referring to climate sciences that draw on mathematical models, computer simulations, and scenarios to generate and communicate power-knowledge of the possible inroads and risks of climate change. The land purchase made by Kiribati's government in Fiji and the related imaginings of migration on the part of citizens in both countries are influenced by this science of anticipation, whose projections of inundation and displacement call into question the future existence of the atoll state of Kiribati and its population. In this context, the acquisition 
of land is due to the aspiration of Kiribati's government, mindful of such future risks, to open up new perspectives on and prospects of survival for its people. The official goal of ensuring Kiribati's future food security may be seen as pursuing a politics of hope, promising I-Kiribati that they can remain in their country for at least the medium term. At the same time, the concrete nature of this step-buying land outside the country-lends particular weight to the discourse concerning the threat posed by the impact of climate change. This anticipation of future risks, in combination with the government's aspiration to open up new, previously uncharted possibilities, paves the way for the imagining of migration as social praxis and resource. This orientation may underlie the readiness of not just I-Kiribati but also the citizens of Fiji to interpret this step as providential-as providing land for the Kiribati nation and the survival of its culture. It is the cultural understanding of land as a basis for social cohesion and cultural identification that moves collective migration or relocation into the realm of the possible. For I-Kiribati themselves, the fact that their government bought land in Fiji therefore stands for hope and the aspiration to preserve the integrity of place, culture, nation, and identity over the long term.

The following account of the imagining of migration is based on longterm and multi-sited anthropological research that we have been conducting with citizens of Kiribati and Fiji. ${ }^{1}$ We wish to stress that the link between this purchase of land and the option of migrating from Kiribati to Fiji is to be seen as less a dominant than an emergent discourse in the two Pacific states. This assessment rests on the fact that almost all our interlocutors volunteered the opinion that the land had been acquired because of the migration option it provided, despite our being careful not to prompt them with questions on the purchase or migration. In ethnographic interviews, we asked them for their views on whether climate change would affect Kiribati (and if so, then in what ways). Expressing their thoughts and emotions on this topic, they eventually communicated what they thought of Kiribati's newly acquired land in Fiji and the possibility of migration. It was only in interviews with representatives of Kiribati's government that we asked about the land purchase. In the case of one indigenous Fijian and his relative, who were showing us around the estate in Vanua Levu, we had merely to ask about its location; they then automatically connected the purchase with the prospect of I-Kiribati resettling there. Our interview findings were complemented by questionnaire responses (I-Kiribati were asked to answer open-ended questions designed to elicit their views on climate change) as well as by the many insights we gained in both countries 
via participant observation. In addition, we analyzed sources produced by the Kiribati government and the media.

As to emergent discourses, we refer to statements that people made to us while we were doing field research from 20I 2 through $20 \mathrm{I} 5$ in both Kiribati and Fiji. Statements testifying to imaginings of migration were expressed clearly during that time frame, as news about the consequences of climate change and Kiribati's land purchase in Fiji consolidated in both Pacific states. Since then the political context in Kiribati has changed, as when the newly elected government under President Taneti Maamau took office in March 20I6. While this new government has replaced the earlier focus on climate change policies with an emphasis on improving people's living conditions in the atoll state, it has also maintained many previous measures designed to reduce Kiribati's vulnerability vis-à-vis climate change. With respect to the purchased land, President Maamau soon took the step of conferring with Fiji's Prime Minister Voreqe Bainimarama, while Kiribati's vice president, Kourabi Nenem, led a delegation to visit the Vanua Levu land tract as early as June 20I6. The new government's plan for the land in Fiji is to carry on where the previous one left off, namely to develop the land and so provide food security for the atoll inhabitants, countering future problems with food supply that might arise due to climate change. ${ }^{2}$

\section{Land Purchase in Fiji: Kiribati Policies}

In the process leading up to the purchase of the large tract of land in Fiji, Kiribati's government of the time explicitly linked the decision to its climate change policy and de-emphasized any possible links to its migration policy. Former President Tong had long made climate change the central focus of his time in office. Speaking at many international forums, he pointed out the existential threat facing atoll states from climate change and called for mitigation of greenhouse gas emissions. Under his leadership, the government also tapped into foreign revenue streams and welcomed international projects to implement adaptive measures. One of these projects, the Kiribati Adaptation Program, seeks to reduce national vulnerability on a variety of fronts, namely, consolidating key infrastructure; ensuring that the population has adequate access to drinking water; raising national awareness of climate change impacts; and planting mangroves to fend off erosion of the coastline. Mindful of the projections disseminated by the climate sciences-which make it seem all too likely that, 
as the twenty-first century advances, atolls will no longer be able to sustain anything like their present population levels—President Tong developed a concept that he called "Migration with Dignity." This concept aimed at education and upskilling, particularly amid the younger generations, in order to provide them with the necessary professional qualifications to find work in their new host countries. They would be able to migrate on a voluntary basis, that is, with "dignity," and once established abroad they would help others follow suit. The idea was to prevent I-Kiribati from becoming refugees and second-class citizens in someone else's country. President Tong notably stressed that migration would not be the total answer to the inroads of climate change and that relocation was only the option of last resort. At the same time, he pointed out that his government had a responsibility to plot a course for the future, to the extent that this lay within its power-and that this was best done by providing a variety of options for its people. ${ }^{3}$

When land became available in Fiji, the government seized the opportunity. In 20I I, Kiribati's high commissioner, Reteta Rimon, learned from a real estate developer she knew that a rural property of more than 5,000 acres on Vanua Levu, Fiji's second largest island, was being offered for sale by the Anglican Church for approximately nine million Australian dollars. After inspecting Natoavatu Estate-the name of this sizeable tract of land-with other representatives of Kiribati and a church trustee, she explained in a position paper for the cabinet how such a property, stretching from the mountains to the ocean, could benefit Kiribati. As she told us in an interview (I 8 Sept 20I 5), her main point in this paper was: "This is freehold and it'll be good for Kiribati long term in the context of climate change, even for food security." She saw the land as ideally suited for agriculture, since food crops could be grown there and a dairy farming sector created, with all the produce being exported to Kiribati by a direct shipping link. Copra production was another option, in view of existing coconut plantations on the estate. Forestry too was worth investigating - pines already grew there; mahogany could be planted and the wood exported back to Kiribati. Even rock could be extracted to consolidate exposed sections of Kiribati's coastline. Finally, this tract of land could be purchased as a long-term security, just in case Kiribati's atolls became uninhabitable. As a more immediate goal, the land lent itself to investment and development.

Trustees of Fiji's Anglican Church and the developer then went to Kiribati to discuss the terms of purchase with the cabinet. After the cabinet had been won over, the next step was for Kiribati's government to negoti- 
ate with its Fijian counterpart. Purchase of freehold land on the scale of the Natoavatu Estate could not proceed without official consent. Then Interim Prime Minister Bainimarama approved the request. The actual purchasing process was a drawn-out affair, since there were several squatters on the Natoavatu Estate for whom the Anglican Church first had to find accommodation somewhere in the vicinity; also, Kiribati's government had to consent to a small parcel of land on the periphery of the estate being excluded from the purchase, since it housed a settlement of descendants of Solomon Islanders. But by the end of May 20I4, Kiribati's president was able to report the acquisition of 5,460 acres of prime Fijian land for the sum of $\mathrm{A} \$ 9.3$ million: "I wish to officially announce that government has come to a final resolve and has made the full purchase of the piece of land in Fiji" (Office of the President, Republic of Kiribati 20I4).

Right from the start of negotiations, Kiribati's government had viewed the land purchase as an economic investment, meaningful in the context of its climate change policy. Given the growing population numbers on Kiribati's atolls and the scientific projections of extreme weather events, members of the government were careful to stress that the new land would be chiefly used to grow food for Kiribati. As President Tong stated: "My Government has also purchased land in Fiji using our meagre resources to assist in our efforts to address the issue of food security and to promote long term development goals" (Tong 20I4; see also Office of the President, Republic of Kiribati 20I4).

Since the international media had published misleading reports of the land being bought for purposes of relocation, government spokespersons repeatedly stressed that it would be used only to produce food, not to resettle those threatened by climate change. The message was scripted not only for an international audience but also for Kiribati's own people. We find it, for example, in an interview Anote Tong gave to the US news channel CNN at the end of June $20 \mathrm{I}_{4}$ (CNN 2OI4), an abridged Kiribati version of which was published in the Kiribati Newstar, headlined: "Ai tii 30 te ririki ao ti a inako!?” ("Only 30 years left till we're submerged!?”). I-Kiribati could now read what their president had to say of their atolls' vulnerability to climate change and what the government was doing about it. Here is an excerpt:

Teuana naba te iango are e a tia ni koro bukina, bon kabooan te aba teuana i Biitii ae e nakon 6,00o te eeka buburana. "Anne bon te aba ae e bubura, te aba ae e rangi n tamaroa." Ma, e katuruturua te beretitenti bwa bon tiaki te 
aba ibukin te maekanaki ma bon te aba ibukin te karikirake ibukin unikan ma karekean te amwarake. (Kiribati Newstar, 4 July 20I4, 3 )

(Also, one of the plans that was realized is the purchase of a piece of land in Fiji that is almost 6,000 acres in size. "This is really a big piece of land, a land that is very good." However, the president emphasized that the land was not intended for relocation but for development, cultivation, and growing food).

Whereas official government statements ruled out relocating all (or most) of Kiribati's population, they were silent on whether the migration of small numbers of I-Kiribati might be countenanced in order to work the new landholdings in Fiji. Sometime after the sale, however, confidential sources told us that while thoughts along those lines had been expressed internally, it had always been emphasized that migration for purposes of working the estate was just one of many options available to Kiribati's citizens. But there were no plans to that effect that could have been discussed with representatives of the Fijian state. Indeed, the reluctance of Kiribati's government to be drawn into a public debate of the issue had much to do with political consideration for Fiji. Kiribati's official representatives were aware of Fijians' specific cultural and political sensitivities over issues concerning land. In addition, Kiribati's government respected Fiji's sovereign status; only Fiji could clarify issues relating to immigration to its shores.

The land purchase was facilitated by a network in which the principal actors possessed knowledge of current discourses circulating in the neighboring states as well as a political history of earlier migrations and relocations between Kiribati and Fiji-for example, in I945, the Banaban community had been resettled in Fiji from Banaba, now part of Kiribati. ${ }^{4}$ The 20I I purchase could only go ahead because these well-informed actors maintained social connections with people from partner countries and cultivated very good political relations. Since the estate had been presented as a rare opportunity, the imperative was for both partners to complete the sale. As for the medium- and long-term perspectives of having some I-Kiribati work the estate, the public on both sides had only been briefly informed that no such negotiations were ongoing. What was brought to public attention was an announcement-made during a February 20I4 state visit to Kiribati by Fiji's president, Ratu Epeli Nailatikau-that Fiji would help I-Kiribati in the event of an emergency. It was in this broader context that the Kiribati government's acquisition of the large tract of land in Fiji caught the attention of many I-Kiribati. Even though it was not publicized as part of the atoll state's migration policy, the fact that it 
was associated with its climate change policy led citizens to understand it through what we may call, with Appadurai (20I3, 289-293), a "politics of hope" designed to transform prospects of climate change-induced disaster into prospects of future survival.

\section{I-Kiribati Attachment to Land And Attitudes TOWARD Migration}

The people of Kiribati received the news of the purchase of the Natoavatu Estate in Fiji within the context of their local and historically rooted conceptualizations regarding land and its relationships to persons, communities, the past, and the present. Indeed, land has always been of existential importance (compare Tito and others I984, 2I), unfolding its significance on various levels: domestic-local, island-regional, and national. Land is the platform around which kinship groups, island communities, and the national community are constituted. Land is what enables Islanders to engage in economic activity, even as it confers on owners and the nation at large a specific political status. In addition, myths on the creation of the islands (see Beiabure, Teraku, and Uriam I984; Uriam I995) and Christian discourses, according to which God gave the land to the people, legitimize the nation's territory in sometimes complementary and sometimes divergent manners (compare Autio 20I0; Camus 20I4). I-Kiribati are proud of their nation and celebrate each year the attainment of sovereignty on I 2 July I979. In the course of subsequent nation building, they have intensified the discourse of Kiribati possessing a unique and distinct culture. Precisely because land is of such fundamental significance, I-Kiribati frequently stress their attachment to it. This interweaving finds expression in the Kiribati term "aba" with its dual meaning of "land/people." Confronted with discourses on the likely consequences of climate change for Kiribati, its citizens emphasize their love for the land and the worries they entertain about its fate (Hermann 20I7). In addition, they articulate a will to do their best for more environmental and coastal protection.

Attachment to land has long been stressed by the citizens of Kiribati in connection with their own internal or international mobility (compare K Teaiwa 20I 5). Countless Islanders have experiences of migration, whether for educational purposes or in search of work. Migrants have frequently articulated their connectedness with Kiribati and previously seemed to view the option of return as self-evident. But one result of climate change discourses has been that migration-minded I-Kiribati are no 
longer sure they will have this option in the future. In this new context, attachment to land matters even more for a majority of I-Kiribati. Not infrequently, a discourse on the intention of remaining on the land can be encountered. This attitude is prevalent in various quarters, as witnessed in this statement by an elderly man from the island of Nonouti: "Ngkana e rotaki Kiribati ni bibitakin kanoan bong ao na mate iaon abau" (If Kiribati is affected by climate change, I will die on my land) (I4 Sept 20II). The perspective of staying put and refusing to leave is often associated with the persuasion that the Christian God holds the fate of humans and land alike in His hands. Until recently, international migration in response to climate change represented for many I-Kiribati an "unthinkable option," as I-Kiribati author Linda Uan and John Anderson wrote (2014, 247). Referring to a national survey they conducted in $20 \mathrm{II}$, these authors went on to say: "The majority of I-Kiribati ( 65 per cent) have no wish to live in another country, ... even though mounting evidence suggests that we may soon have little choice in the matter. Migration may unavoidably soon become the major element of adaptation" (Uan and Anderson 20I4, 247).

In connection with migration, the citizens of Kiribati are well aware of the restrictions imposed by their scant economic resources. Since discourse on rising sea levels has exerted an unsettling effect on many atoll dwellers, a recent trend-observed across all generations-has been toward a spectrum of discourses on migration. These include a constellation of statements voicing the intention to do whatever it takes to preserve the land and, only as a final resort, to seek to migrate. A variant of this discourse was enunciated by a young man (aged seventeen) from the island of Nikunau, who mentioned the possibility of Kiribati acquiring a piece of land in another state:

When my mother country (Kiribati) is affected by the climate change nowadays, I have many methods to [protect] our country from this dangerous problem, such as planting more mangroves for saving our land from the erosion, telling people to [protect] the life of plants and stop deforestation, and especially telling powerful countries to stop testing their nuclear weapons in the Pacific region and requesting them to give a piece of land for the Kiribati people to live in their countries. (I4 Sept 20IO) ${ }^{5}$

Migration for some I-Kiribati is associated with the option of moving to Fiji. As one pastor, who identified as both I-Kiribati and Fiji Banaban, reported, that country was being mentioned by the parish youth as a possible destination in the worst-case scenario: "And sometimes they might 
say: 'Oh maybe we'll have to move to a country that is high enough for us to stay-like Fiji'” (I6 July 20I4). The pastor himself thought that, if migration were ever to become unavoidable, Fiji would be preferable to Australia or New Zealand "because you are moving from one place in the Pacific to another. And you can connect a little bit easier to people and to the place. There is an understanding, you know, between Pacific Islanders." Thus, to more than a few atoll dwellers, Fiji seemed a feasible destination in the event of climate-induced migration. So when the government of the atoll state acquired a tract of land there, Fiji loomed ever larger in I-Kiribati imaginings of migration.

This emerging shift in attitudes toward migration is connected to a growing fear of loss of land (aba) among I-Kiribati. As land has always been contested between competing groups and is, in any case, subject to environmental change, there has been concern over its partial loss to an extent in the past. But this sense of loss is aggravated nowadays since changes in the environment such as erosion and inundation are being reinterpreted in the context of climate change. What we now find is that the concept of the land (te aba) - referring to Kiribati's atolls-is in the process of changing from something that protects people to something that is in need of protection and may even be doomed. Confronted with statements like the one published in the Kiribati Newstar of 4 July 20 I 4 (cited above), implying that the atolls could be submerged thirty years from now, many I-Kiribati say, sadly: "E na bua abara ae Kiribati" (Our land of Kiribati will be lost). Thus the probability of the climate change projections mediated by the media and government campaigns lead quite a number I-Kiribati to anticipate the near total loss of their national territory in the future.

\section{An Emerging Kiribati Discourse on Migration with the Prospect of Land in Fiji}

After their government announced in $20 \mathrm{I} 2$ that it would purchase Natoavatu Estate in Fiji, an increasing number of Kiribati's citizens began expressing views on the matter. Some I-Kiribati understood that their government intended to use the land primarily for agricultural purposes. Among these were climate change skeptics, who saw the whole matter in an economic or commercial light, but there were others who were convinced that Kiribati was at risk from the consequences of climate change and therefore had to do something to ensure food security. Other I-Kiribati 
who had heard what their government was up to even before the purchase made no mention of the government's stated goals; instead, they instantly associated this vast tract of real estate with climate-induced migration to Fiji. In their entirety, these statements make up a discursive formation initially triggered by the news about the land acquisition in Fiji. Yet this discourse, in which land in Fiji is tentatively linked to migration, is not incompatible with the deep attachment I-Kiribati have to their lands, to their home islands, to Kiribati itself. Rather, the new discourse is taking shape in association with the existing one. Thus, while our interlocutors typically stressed their close ties with their Kiribati homeland, they were careful to note that, in the worst-case scenario, they could not rule out migration to this newly acquired estate; after all, there might be no other alternative.

The tendency to articulate attachment to the land while simultaneously imagining migration as an option in the face of climate change was evidenced in what we were told by a retired teacher now living on Nonouti Atoll in southern Kiribati. She had in younger years gone to Britain to complete her studies; on returning, she had taught on a number of islands before finally settling down on her home island of Nonouti. Whether during trips we made with her along the atoll or in the course of our many conversations, she repeatedly dwelled on her strong feeling of belongingnot only to her home atoll but also to Kiribati as a nation. In one interview, after telling us she greatly appreciated Nonouti's peaceful lifestyle, she began to reflect on what rising sea levels might mean for that island, as well as for the rest of Kiribati. She confessed to a sense of fear. Admittedly, her own advanced age made it unlikely that she would herself be affected, but younger and future generations might be. And she hoped that if worse came to worst, they might be able to relocate to a better place. She speculated as to whether rising seas were the reason why, as she put it, "some people have started to evacuate to New Zealand." She then added that perhaps her compatriots could also resettle on the higher island of Banaba or even go to Rabi, the Fijian island home of the Banabans. On the subject of Fiji, she commented tellingly: "The government is buying a piece of land in Fiji, our government! So maybe it is thinking of evacuating the people there" (22 Sept 20I2). Thus she alluded to two kinds of possible migration (in the sense of evacuation): one was individual, the other collective. The first of these meant that some people had already moved to New Zealand, but as individuals. She mentioned this option, since her own son (with his family) was attempting to emigrate there, where he had 
affinal relatives. On the other hand, she implied-referring to the estate purchased by her government - that, if the worst ever happened, collective relocation was the only answer. By talking of "our government," she was signaling that the latter would act on behalf of a nation under threat.

Also living on Nonouti was a middle-aged man who, after retiring from working as a seaman, had held a responsible post with the local council. He related that when the news came through of the planned purchase, some had thought of leaving their island. In our interview about local environmental changes, he mentioned hearing a radio broadcast on rising sea levels. He also heard on the radio of an I-Kiribati who had justified staying in New Zealand by claiming that Kiribati was threatened by rising waters. Many of his fellow countrymen, he added, would reject emigrating for such a reason, preferring to place their trust in God. He concluded, "Now when they heard that the Kiribati Government had land in Fiji, some people said: 'So it's better we go and live there!' But not all agreed. Some [said]: 'Ah! We can't go, we must stay!'” (23 Sept 20I2). When asked whether he thought more people would want to stay than leave, he said he did not know; he could only speak for himself: "But as for me: okay, I want to leave. I want to leave here. I don't want to die here. It's better for me to [take] my family [and] go and live somewhere [else]." In answer to the question where that might be, he said simply: "Fiji." In the further course of our interview, he added that he would be staying put for the time being, since life on Nonouti was so peaceful. For him, relocation would only be an option if the threat from higher waters became acute: "When I listen to the radio—the sea rising and what not—for me: okay, it's better to leave. But how can you leave? Okay, no problem if there is transport to Fiji for those who want to go there, like free of charge. Okay!"

Our interlocutor understood-and he insisted this was an understanding shared by some of his fellow Islanders-the efforts of Kiribati's government to acquire land in Fiji solely in terms of finding a suitable place for resettlement. He was worried about the expense of relocating there, but he was certain this problem could be solved with economic assistancewhich, he implied, would be provided by his government.

Nor was talk of the government's intention to purchase land in Fiji lost on the younger generations; rather, it became factored into their thinking about the best course of action in the worst-case scenario. Thus a female high school student, age sixteen, alluded to the purchase in a questionnaire. Answering the question, "If Kiribati is affected by climate change, what will you do?" she said that she intended to get more education, so 
that one day she could hold down a responsible position, "maybe [even that] of a president." Then she imagined being president and gave a list of possibilities "for saving my people." Her third option was "I will purchase one big tract of land in a big country, so that when the time comes I can move my people there" (8 Oct 20I3). In an interview a year later, she let us know that her adoptive father had informed her that President Tong was going to acquire a large estate in Fiji. She was even precise: a year earlier the purchase had not yet gone ahead, she said, but now it had. And she added: "I have already seen the picture of the land in one of the newspapers, maybe in Te Uekera [the national weekly] or the Newstar" (2I July 20I4). This girl, whose place of birth was the island of Abemama, had grown up in Tarawa and, through her adoptive father, who had once been a member of Parliament, she had an insider's access to Kiribati governmental politics. Her vision confirms impressively the association now being made by I-Kiribati with this land purchase, namely, that the goal is to create a new home for them should catastrophe strike.

Moreover, representatives of the Catholic Church, Kiribati's largest denomination, associated climate change and its likely aftermath with the land purchase in Fiji and the option of migrating. One elderly member of the Catholic ruling circle had this to say in an interview:

There are certain things we can do to protect ourselves. And there are certain things we can't do anything about. So the government is encouraging building seawalls. To stop the erosion. But if the sea rises a lot, if it's very high, you know, very high, then you can't do anything about it.

Question: What then?

Answer: Well, that's it. That's why the government bought the land in Fiji. As a kind of preparation, I mean if we have to leave the islands. And I think we will have to. There is no question about it. Because of the sea rising. (I2 July 20I4)

So this Catholic churchman understood the purchase primarily as a precautionary measure, if rising seas ever compelled emigration.

Among those Kiribati citizens who, in the period since 20I 2, have taken to imagining that the purchase might eventually serve as a relocation point are a number of Banabans. Most of them are from Rabi Island in Fiji and have lived on Tarawa for decades-often after first spending many years on Banaba (Kempf forthcoming). Some are well informed about the government's plans. Still, most Rabi Banabans imagine that this Fiji land could, in the final resort, serve as a new home for the I-Kiribati. 
A respected Banaban elder, a man with no lack of political experience, explained it thus:

They [the government of Kiribati] bought the land on Vanua Levu. I don't know, maybe this is another solution. They think of development, but for me personally, I think it's better to get more Gilbertese over there, marry the Fijians, marry the Banabans. That's how they can improve the future of Kiribati. (28 Sept 20I3)

In fact, Rabi Banabans have no intention of availing themselves of this option, since they consider Rabi a safe haven (compare Kempf and Hermann 20I4, 205); however, many of them consider relocation an option for the atoll inhabitants of the Gilbert Islands, the I-Kiribati.

A related discourse can also be heard from Banabans living on Banaba but who periodically come to Tarawa. One Banaban man in his thirties had attended (presumably in 20I2) a workshop on Tarawa organized by the Office of the President on the topic of climate change. Talking to us two years later, he recalled that the possibility of emigration to Fiji had been discussed at the time. The message had been that in ten or twenty years Kiribati would disappear below the waves. When asked what would then become of its people, he again referred to the Fijian land purchase. One Banaban woman in her early forties, who had also been participating in our conversations, explained: "But you know, our government bought an island [sic] over there in Fiji, so the Kiribati people could go and live there" (22 July 20I4). When we inquired of these two Banabans what they felt about migrating, they explained that if they continued to live on Banaba, they would want to stay put. Because Banaba is a raised limestone island, they feel perfectly safe there. But, they continued, if they were living on Tarawa and climate change made it impossible to remain, they would want to relocate to Fiji.

As it happened, word of the purchase also reached I-Kiribati already living in Fiji. They found themselves confronted with the belief of some Fijians that the new land on Vanua Levu was acquired solely for an impending relocation of Kiribati's population. A middle-aged man, who had long worked on Tarawa as a pastor with the Kiribati Protestant Church and who was now enrolled at the University of the South Pacific in Suva, explained:

Most of the Fijians say that Kiribati is now under the water, because [our] government has already purchased land here in Fiji.... And most of them say: "Hey, are you from Kiribati?"- "Yes."- "What happened to your island? Is 
[it] under water now?" - "No." Sometimes they [seem] annoyed to hear that, and say: "But we heard that your government had already purchased land here in Fiji for your people to migrate to.” Just like that. (I 5 Aug 20I4)

During our interview, it emerged that this generalizing version of the dialogue with Fijians was based on a true incident. Our interlocutor from Kiribati was in a Vodafone store when an unknown Fijian started talking to him. The Fijian's sudden and (we may assume) provocative manner-calling him out in public as a foreigner and confronting him on the issue of land and resettlement-only underlined the tensions surrounding the topic. Not without reason, the man from Kiribati supposed that the purchase of such a large property by a foreign government had caused some irritation among indigenous Fijians. Whereas, in the encounter with Fijians, the use of the property as settlement land appeared as an acknowledged given, from our I-Kiribati interlocutor's perspective the matter was still shrouded in uncertainty:

I am not sure about the land. Is it land for migration or is it for a government development project or something like that? If for migration I think the [plan is unworkable] - the land cannot [accommodate] them. I think the population of Kiribati is now almost I00,000. . . . It's confusing. . . . But that's another issue. . . . I-Kiribati talk about it: "What's the land for? Who are the people that are going to benefit from the land? Who will be the first to go and live there, to work there? And if the land is for a project-for development, when is it going to start?" . . . Maybe the government is thinking ahead to the next generation. That could be it. Anyway, most people are now talking about the land purchase here in Fiji. (I 5 Aug 20I4)

In the opinion of this migrant, the purchase and its future use by Kiribati's government raised more questions than answers. True, the government's postulated preference for development projects seemed a more likely explanation than resettling the entire Kiribati population, and yet even a commercial utilization of the property would pose some difficulties.

In sum, all these statements by citizens of Kiribati indicate the emergence of a discourse linking the land purchase with migration to Fiji. Whether our interlocutors came from atolls, from Banaba, from Rabi Island in Fiji (albeit now living in the atoll state), or were I-Kiribati migrants living in Fiji, all spontaneously associated climate change or sea level rise with the purchase. In each case, a causal connection was operating: the latter was rendered inevitable by the former. Certainly, they argued, their government had been mindful of the possible effects of climate change on 
Kiribati when it bought this tract of foreign land for the national community. Thus the purchase made the prospect of major inroads from climate change seem more likely. Accordingly, most of our interlocutors associated the land purchase with migration-as a final measure if and when all else failed. Some were personally thinking of migrating, and many associated collective relocation with the estate in Fiji now owned by Kiribati. Our interlocutors' imaginings of migration can be traced back to their agency—an agency manifested in the articulation of a will to make plans and take the initiative, as Appadurai (1996, 200I) as well as Patricia Pessar and Sarah Mahler (2003, 8I7) would have it.

\section{EMERging Discourses on I-Kiribati Migration Amid Citizens of Fiji}

During a state visit to Kiribati in February 20I4, President Ratu Epeli Nailatikau assured his hosts of Fiji's unlimited solidarity in the worst-case scenario. He was reiterating that Kiribati's people could count on his government's willingness to offer them refuge in such circumstances:

Today I repeat what our Prime Minister told the world at the recent Pacific Islands conference on conservation and protected areas. If the sea level continues to rise because the international community won't tackle global warming, some or all of the people of Kiribati may have to come and live in Fiji. (Fijian Government Online Portal 20I4)

The land acquisition by Kiribati's government was cited as a current expression of the close historical ties linking the two countries. As to the concrete utilization of the estate, the president of Fiji had this to say:

You have already purchased 6000 acres of land on Fiji's second biggest island, Vanua Levu, to ensure your food security as the sea encroaches on your arable land. What the future holds we cannot say. But I want to assure you that if all else fails, you have true friends in Fiji who will not let you down. (Fijian Government Online Portal 20I4)

With these assurances, President Nailatikau was continuing the political line of the interim government of Fiji, which had held out especially to the neighboring atoll states of Tuvalu and Kiribati the prospect of support in connection with climate change-induced displacement (Radio New Zealand 2009; Bainimarama 20I3; compare Bedford and Bedford 20I0, 90).

The fact that representatives of the government of Fiji took to pro- 
moting the imagining of migration as part of their climate change policy was, in our view, politically motivated. Fiji was demonstrating that it too belonged among the vulnerable Pacific Island states, the better to position itself against all those industrial states that had been identified as responsible for the dangerous consequences of climate change. On the regional level, Fiji's interim government was demonstrating solidarity with the neighboring atoll states, in contrast to Australia and New Zealand, which had rejected admitting so-called climate refugees (compare Korauaba $2015,234)$. Agreeing to sell freehold land to a neighboring atoll state fitted in with the profile Fiji's government was seeking to project under its regional foreign policy. This is all the more remarkable given that freehold land had been generally of political significance (and contested) in the past. Some ethnonationalist Fijians, especially, had persistently demanded the return of all freehold land, and some talked of freehold land "alienated before cession [to the British]," which they saw as having been unlawfully taken from the original owners (see Lal 2006, 42, I36-I37, I94-I95). The decision taken by the military government under Bainimarama to combine this international transaction with their regional climate change policy was driven by a determination to draw attention to Fiji's claim to political leadership in the region. ${ }^{6}$

News of the purchase encountered, in Fiji itself, a specific terrain of climate change discourses and awareness campaigns; national programs on disaster risk management, mitigation, adaptation, and relocation; efforts to integrate indigenous Fijian interests; and media representations of the hazards facing Fiji's islands, villages, and urban centers, as well as neighboring atoll states. In 2012 the cabinet of the Fijian government, headed by Prime Minister Bainimarama, adopted a national climate change policy (Government of the Republic of Fiji 20I2). The task of coordinating, overseeing, and implementing it was handed to the Climate Change Division of the Ministry of Foreign Affairs and International Cooperation. Government representatives estimate that there are some $600-800$ communities in Fiji who, in one way or another, are affected by the consequences of climate change. In this connection, the government attaches great importance to internal relocation as an adaptive measure. According to official plans, some forty-two villages are to be relocated over a period of five to ten years. Between 2OI 4 and 2OI 5 the first relocations of Fijian village communities took place: Vunidogoloa on Vanua Levu, Narikoso on Kadavu, and Denimanu on Yadua Island in Bua. The government bodies in charge were endeavoring to draw on the lessons learned from these 
pilot projects in order to revise existing relocation guidelines with future relocations in mind (Fijian Government Online Portal 2015).

It is likely no accident that Fiji's interim government celebrated at the start of 2014 the successful realization of the first climate-induced relocation of a Fijian village (Vunidogoloa), in Cakaudrove, that is, the same province on Vanua Levu where the government of Kiribati would only a few months later officially purchase the Natoavatu Estate. The relocation of this village was meant to serve as a model. The point for Fiji's government was to present the country's "first" climate-induced resettlement project as a template for all planned resettlements to come (Bainimarama 20I4; Rawalai 20I4). Since the relocation of Fijian villages draws considerably on indigenous Fijian (iTaukei) concepts of land, the driving idea behind this pilot project was to demonstrate the government's ability to act and its competency, openness to dialogue, and cultural sensitivity in implementing such measures. Moreover, the timing can be seen as signaling governmental resolve to prioritize the aspirations and demands of ethnic Fijians vis-à-vis climate change and sea level rise, even if an allied atoll state like Kiribati should likewise be in need of solidarity from the Fijian state.

Land (vanua) is of fundamental importance for iTaukei. During the colonial era, in order to protect ethnic Fijians from dispossession and exploitation, much of the land was linked to social groups and hierarchical structures and codified as inalienable, communal property (France I969; Lal I992, 28-33, 97-I02, 224-227; Kaplan 2004, 73, 76). Based on these historical developments, today's iTaukei see themselves as the lawful owners and guardians of the land of their forebears. Land and landownership are for them central planks of Fijian belonging, community, culture, and ethnic identity. The concept vakavanua (the way of the land) points to this reticulation between land, people, traditions, and socioeconomic structures. And yet iTaukei see this established privilegethat they are the rightful owners of the land-as repeatedly threatened. Matt Tomlinson has, in this connection, analyzed how historical rivalries and contradictions between the Methodist church and the Fijian chiefs promote and perpetuate indigenous notions of decline and loss of former supremacy, ancestral strength, and powerful traditions, but also a ritual and political praxis of recuperation, reclamation, and hope (2009, 5-6). The discourse of a vanua at threat from the outside is, according to Tomlinson, a historical constant, primarily manifested in recent decades by the conviction that Fijian land must be protected from takeover by Indo- 
Fijians, who form the second largest of Fiji's ethnic groups (see Tomlinson 2009, I32-I4I).

If climate change gives rise to relocations, this could imply the loss of land, as John Campbell has argued in general terms for the Pacific Islands (2010, 64). In the case of Fiji, it is to be noted that the recent idea of a Fijian vanua threatened by the consequences of climate change and sea level rise adds yet another dimension to the existing discourses and practices of loss and recuperation. Fiji's interim government associated its national climate change policy largely with the (potential) loss of habitable land and the administrative option of restoration via relocation projects. ${ }^{7}$ Especially in the areas deemed affected, ethnic Fijians have internalized the discourse on climate change and relocation, the better to reconstitute, consolidate, and perpetuate their identity as iTaukei. The headman of the relocated village of Vunidogoloa, speaking in August 20I4 at a workshop of the Nansen Initiative, reflected this perspective:

I am a victim of climate change. All my life I was brought up in the climate change zone.... What makes it easier for this relocation project is the community's willingness to relocate. Even before they were being approached by the government, they were ready to relocate because of the climate change affecting the areas where we live.... When I talk as a victim of climate change it really touches me, because I've been a victim of climate change all my life. I thank the government-also the NGOs-for helping my village and my community to relocate. (I8 Aug 20I4)

The headman went on to state that his parents' generation had already wanted to move their village inland, owing to changing coastal ecology; what had ultimately deterred them, though, were economic constraints. By depicting himself as a victim of climate change, he was vicariously underlining-standing proxy for his fellow villagers-a decades-long sense of vulnerability, of distress and neediness, which could finally be overcome with external help, especially from the interim government. The indigenous narrative of victimhood in the face of climate change, of living in a zone of decline and loss, appeals to the economic solidarity and political responsibility of the Fijian government, which is expected to assure the survival of imperiled iTaukei communities by adaptive measures like relocation and permanently strengthening their powers of resilience.

The local effects of, and indigenous experiences with, climate change in the Fijian province of Cakaudrove, caused the then Roko Tui Cakaudrove, representing the Fijian administration at the provincial level, to justify 
the necessity and urgency of resettling five high-risk communities. ${ }^{8}$ Referring to the successful implementation of the climate-induced relocation of Vunidogoloa that fell under his jurisdiction, he confirmed not only the generally existing vulnerabilities and threats but also a general sense of crisis facing parts of the province; he went on to announce that more resettlements of iTaukei communities would follow:

There are increasing requests from villagers to relocate. This has even reached the Prime Minister's office.... We have one village relocated already and there is another one ready for relocation through the USAID project. [We have] erosion of the coastal fronts of villages. We have cases of dried-up streams, rivers and drinking water running out. Not only that. In Cakaudrove, [we have had the] first case of relocation and-then there is a piece of land being bought by the Kiribati Government for development purposes. Because the rumor we first heard was that [the land] was for them to be relocated there, but now we are hearing something different. It is for food security and other developmental business by Kiribati's Government. So we are both the victim and the helper [in the context] of climate change. (I8 Aug 20I4)

Thus, the successful relocation of the village of Vunidogoloa in Cakaudrove served in the Roko Tui's remarks as a model for how to save Fijian victims of the impending decline and loss of vanua due to the inroads of climate change. The presenter connected this example of a national politics of hope on the part of the interim government with its international politics of hope. If the land purchase by Kiribati's government was primarily associated in people's minds with settlement by the population of the atoll state, this was due to dominant Fijian conceptions and politics of a linkage between climate change and resettlement, between loss and restoration. Although the help that Fiji has been willing to provide by approving the transaction of freehold land to Kiribati was agreed to in terms of assisting its neighbor with developmental opportunities and options for food security, the possibility of migration had not been excluded over the longer term. Here a crucial role is played by the vanua concept, which renders it plausible to iTaukei that I-Kiribati need the new land to assure survival as a community, culture, and nation. Against this background, we may assume that Kiribati's land purchase will permanently reshape local realities, constellations, and perspectives as well as impact future discourses and practices of indigenous Fijians on climate change and sea level rise in Cakaudrove (and beyond).

News of the sale of land to the Kiribati state was also closely followed by citizens of Fiji living on Vanua Levu who are connected to Kiribati. 
From conversations with persons from the Savusavu region, it became clear that television coverage of the purchase had attracted notice and concern. Swayed by alarmist representations of low-lying atolls, high waves, and inundated areas, these persons expected settlers from Kiribati to be landing on their shores at any moment. After a collective tour of the Natoavatu Estate, a Fijian man in his mid-fifties who was related to descendants of immigrants from the Gilbert Islands (now Kiribati), explained: "We were just waiting for one big ship to bring them across!" (3 Aug 20I4). And a younger relative of his added: "We were expecting the town [Savusavu] to be full of Gilbertese!" Many of our interlocutors were surprised when they heard our own account of Kiribati's official statement to the effect that the land was primarily intended for future food security in the atoll state.

Banabans living in Fiji also followed the news of the Kiribati government's purchase with great interest. Via reports in Fijian newspapers and a radio program in their own language, the Banaban community learned that sea level rise was a major threat to low-lying Kiribati. Soon they began to worry about their relatives on the atolls. In our conversations, Fiji Banabans often drew a link between the threat and the land purchase. A well-informed representative of the administration on Rabi Island, a man who had closely followed the parliamentary debates in Kiribati, told us he believed that the government there was pursuing two objectives: first, it was for them "a food security issue"; second, the land was intended "for migration"- so they would have a "place to stay" (5 Aug 20I4). Apart from this man, few of the other Rabi Banabans had heard of the first objective. All that the majority had taken away from the media representations and local conversations was that the estate had been bought with future migration in mind.

We cite here just one more of many other Banaban voices, that of a woman who in recent years had twice visited members of her family living on Tarawa, where she had learned about the effects of climate change in Kiribati. She expressed her general concerns about the threat from a rising ocean, before mentioning in connection with the I-Kiribati: "And I think the land bought here was bought for them.... It was all in the news.... But they don't want to come, because they love their own land. ... Their President bought it [the land in Fiji] for them because of the sea [coming] very near now to the land [the atolls]" (9 Aug 20I4). This lady saw the land acquired in Fiji as a way out for the atoll inhabitants, who had long struggled with overpopulation and were now additionally having to con- 
tend with an eroding coastline. Like the others, she wondered when the I-Kiribati would be arriving. Asked why she thought the land in Vanua Levu had been acquired, her answer was clear: "For them to move there" (9 Aug 20I4). Like other citizens of Fiji, she associated the purchase with the collective migration of I-Kiribati.

\section{Conclusion: LAND AND The IMAgining OF Migration}

The land purchase in Fiji signaled for a broad spectrum of Kiribati's people a new phase in the debate over threats from climate change and sea level rise. The systematic planning and implementation of an economic transaction of this magnitude-subsequently approved by Fiji's interim government-had the effect of verifying the official discourse of an unavoidably endangered Kiribati. Yet despite the Kiribati government focusing on the economics underlying its purchase, especially the contribution it might make to the country's food security, many I-Kiribati instead associated it with migration and resettlement. This indigenous imagining of migration points to two intermeshed ways of constituting the future. First, the risk to land and people anticipated by the government led to a situation where I-Kiribati increasingly linked land, locality, and population to vulnerability, crisis, and the prospect of displacement. Second, the Islanders viewed their new land via the lens of a politics of hope, with their government providing a safe place of refuge in case their home atolls ever became uninhabitable.

The imagining of migration, propelled by Kiribati's government's land purchase in Fiji, was fostered by the policies of the two Pacific states as well as by concepts of land harbored by their citizens. Thus this imagining of migration has to be seen in the context of Kiribati's climate change policy but also its migration policy. Despite the fact that acquiring land was never part of the government's policy and scheme of "Migration with Dignity," many I-Kiribati saw the transaction rather differentlyas furnishing an additional option for future migration and settlement. The official model of further education and training in the workplace, intended to inculcate the very skills needed to find work in Australia and New Zealand, connotes for many Islanders the stressful side of competition, not to say uncertainty, inferiority, and alienation. By contrast, the newly acquired land in Fiji holds out the prospect of a concrete place, in a neighboring Pacific state, combining the qualities of reachability, accessibility, and economic viability with those of cultural, social, and political 
compatibility. One core aspect that helps make migration imaginable is the cultural significance of land. This prompts I-Kiribati to assume that their government's acquisition serves the purpose of collective settlement. Land evokes community, inspiring the hope that cultural solidarity can be maintained in the future. Land and collectivity guarantee, in turn, the continuity of cultural practices and identifications as I-Kiribati. Hence, land acquired by the state leads them to aspire to security and survival of family, community, culture, and nation.

Comparable conceptions of land in combination with media representations of the vulnerability of neighboring atoll states, additionally compounded by official declarations of solidarity from Fiji's interim government, cause even indigenous Fijians and Fiji Banabans to associate this land acquisition by Kiribati's government predominantly with migration and resettlement. Kiribati's new estate on Vanua Levu is situated within a broader landscape of historical and present-day relocations. The northern region within Fiji has recently seen the implementation of a future-oriented national policy of climate-induced resettlement of iTaukei communities. Given this background, the purchase by Kiribati's government will influence and modify social and cultural relations, including the overall balance of forces and the constituting of a regional future in Cakaudrove. Hence, the confluence of international and national climate change policies in the country's north is staking out a future terrain of competing (imaginings of) relocations, aspirations, and belongings. Land in Fiji was, and remains, a highly charged political issue. In the case of the Natoavatu Estate on Vanua Levu, Fiji's military-led interim government sanctioned the acquisition of an extensive tract of freehold land by one of its Pacific neighbors. This arrangement is part of the government's policy to underscore its own claim to leadership in the southwestern Pacific by promising to take in the inhabitants of the nearby atoll states, should they be displaced by the consequences of climate change. This Fijian politics of hope-coming at a time when Australia and New Zealand are refusing to countenance climate-induced migration-is primarily intended to advance alternative solutions, to organize specific alliances between Pacific Island states, and to demonstrate their power to act.

Imaginings of migration by citizens of Kiribati and Fiji give evidence of their agency. People in both Pacific states actively conceptualize ways in which they might be affected collectively by possible impacts of climate change. But they do not see themselves solely as victims of these threatening impacts. Instead, they imagine possible ways of acting, hop- 
ing that their respective lands will lend themselves to linking past and future.

WE ARE DEEPLY GRATEFUl to all who welcomed us on their islands, shared their views on climate change, or cooperated in this research. Many thanks to all our interlocutors, including representatives of national and local governments, friends, and adopted relatives. We are greatly indebted to the anonymous reviewers for their valuable suggestions. Our sincere thanks to Bruce Allen for correcting our English version and to Steffen Herrmann for his help in preparing the manuscript for publication.

\section{Notes}

I Since 2009, we have spent roughly a month each year in Kiribati (mainly on Tarawa, Nonouti, and Onotoa) researching the reception of climate change. In Fiji, we have been engaging in research with resettled Banabans since 1996 (see, eg, Hermann 2005; Kempf and Hermann 2005; Kempf 20I 2).

2 We owe this information to interviews with President Taneti Maamau (7 Sept 2016); Vice President Kourabi Nenem (22 Aug 20I6); Minister for Environment, Lands and Agricultural Development Tebao Awerika (I Sept 20I6); and Minister for Labour and Human Resources Ruateki Tekaiara (I Sept 20I6).

3 Information on Kiribati's policies on migration between 2003 and 2015 derives from interviews with the former president of the Republic of Kiribati, Anote Tong (I4 Sept 2009); the deputy secretary of the Ministry of Foreign Affairs and Immigration (7 Sept 2009); a representative of the Ministry of Labour (22 Sept 20IO); the officer for Foreign Office and Public Relations (3I Aug 20I 5); and the high commissioner of Kiribati in Fiji (I8 Sept 20I5).

4 On the relocation of the Banabans to Rabi Island in Fiji, see Silverman I97I; T Teaiwa 1997; Hermann 2003; Kempf 20I 2; K Teaiwa 2015.

5 This and the following quotations (taken from statements made in English by non-native speakers) were slightly edited in the interest of correct English.

6 Compare Fraenkel 20I5, 5I6-5I7, regarding Fiji's claim to leadership in the region.

7 The Christian churches of Fiji, including the Methodist church, are an integral part of this process. Their task is to meet fear of climate change with the promise of hope and healing. In this connection, climate-induced resettlement is associated with departing for the Promised Land. Communities that are expected to make land available for the relocation of others would have to accept the responsibility on the basis of the parable of the Good Samaritan (Peter Emberson, 
pers comm, 20 July 20I2). But to pursue this aspect here would take us too far afield.

8 "Climate Change Impacts and Experiences in Vanua Levu: A Case Study of Cakaudrove Province," a presentation given by the Roko Tui Cakaudrove at the Pacific Regional Civil Society Organisations Workshop, hosted by the Nansen Initiative (August 20I4).

\section{References}

Appadurai, Arjun

I996 Modernity at Large: Cultural Dimensions of Globalization. Minneapolis: University of Minnesota Press.

200I Grassroots Globalization and the Research Imagination. In Globalization, edited by Arjun Appadurai, I-2I. Durham, NC: Duke University Press.

2013 The Future as Cultural Fact: Essays on the Global Condition. London: Verso.

Autio, Petra M

2010 Hard Custom, Hard Dance: Social Organisation, (Un)Differentiation and Notions of Power in a Tabiteuean Community, Southern Kiribati. Helsinki: Helsinki University Press.

Bainimarama, Voreqe

2013 Fijian Prime Minister Voreqe Bainimarama Speech at the Closing of the 9th Pacific Islands Conference on Conservation and Protected Areas. 6 December. http://bainimarama.org/fijian-prime-minister-voreqe -bainimarama-speech-closing-9th-pacific-islands-conference -conservation-protected-areas/ [accessed 2I Jan 20I7]

20I4 Speech at the Launch of the Vunidogoloa Village Relocation Project. I6 January. http://web.archive.org/web/20I4I I06042208/http:// www.psc.gov.fj/index.php/psc-news/speeches/829-prime-minister -commodore-j-v-bainimarama-speech-at-the-launch-of-the -vunidogoloa-village-relocation-project; 7.5 I minute video including speech: https://www.youtube.com/watch?v=_7 $\mathrm{C}_{9} \mathrm{~h}_{2} \mathrm{~F}_{5} \mathrm{FVs}$ [accessed I6 March 20I7]

Barnett, Jon

2005 Titanic States? Impacts and Responses to Climate Change in the

Pacific Islands. Journal of International Affairs 59:203-219.

Barnett, Jon, and Neil W Adger

2003 Climate Dangers and Atoll Countries. Climatic Change 6I (3): 32 I337.

Barnett, Jon, and John Campbell

2010 Climate Change and Small Island States: Power, Knowledge and the South Pacific. London: Earthscan. 
Barnett, Jon, and Saffron J O’Neill

2012 Islands, Resettlement and Adaptation. Nature Climate Change 2:8Io.

Barnett, Jon, and Michael Webber

20I0 Migration as Adaptation: Opportunities and Limits. In Climate Change and Displacement: Multidisciplinary Perspectives, edited by Jane McAdam, 37-55. Oxford: Hart Publishing.

Bedford, Richard, and Charlotte Bedford

2010 International Migration and Climate Change: A Post-Copenhagen Perspective on Options for Kiribati and Tuvalu. In Climate Change and Migration: South Pacific Perspectives, edited by Bruce Burson, 89-I34. Wellington: Institute of Policy Studies.

Beiabure, Meita, Tetika Teraku, and Kumon Uriam

I984 Creation: The Work of the Gods. In Kiribati: Aspects of History, by Sister Alaima Talu and others, I-6. Suva: Institute for Pacific Studies and Extension Services, University of the South Pacific; Tarawa: Kiribati Ministry of Education, Training and Culture. First published in 1979.

Campbell, John R

2010 Climate-Induced Community Relocation in the Pacific: The Meaning and Importance of Land. In Climate Change and Displacement: Multidisciplinary Perspectives, edited by Jane McAdam, 57-79. Oxford: Hart Publishing.

20I4 Climate-Change Migration in the Pacific. The Contemporary Pacific 26:I-28.

Campbell, John, and Richard Bedford

2014 Migration and Climate Change in Oceania. In People on the Move in a Changing Climate: The Regional Impact of Environmental Change on Migration, edited by Etienne Piguet and Frank Laczko, I77-204. Dordrecht: Springer.

Camus, Guigone

20I4 Tabiteuea: Kiribati. Geneva: Fondation culturelle Musée BarbierMueller.

Clifford, James

I997 Routes: Travel and Translation in the Late Twentieth Century. Cambridge, MA: Harvard University Press.

CNN

20I4 President of Kiribati Anote Tong on Climate Change: "It's too late for us" on CNN's Fareed Zakaria GPS. 8 June. Video and transcript: http://cnnpressroom.blogs.cnn.com/20I 4/06/o8/president-of -kiribati-anote-tong-on-climate-change-its-too-late-for-us-on-cnns -fareed-zakaria-gps/ [accessed 20 March 20I7] 
Connell, John

2015 Vulnerable Islands: Climate Change, Tectonic Change, and Changing Livelihoods in the Western Pacific. The Contemporary Pacific 27:I-36.

Dawson, Andrew, and Mark Johnson

$200 \mathrm{I}$ Migration, Exile and Landscapes of the Imagination. In Contested Landscapes: Movement, Exile and Place, edited by Barbara Bender and Margot Winer, 319-332. Oxford: Berg.

Farbotko, Carol, and Heather Lazrus

2012 The First Climate Refugees? Contesting Global Narratives of Climate Change in Tuvalu. Global Environmental Change 22 (2): 382-390.

Farbotko, Carol, Elaine Stratford, and Heather Lazrus

2016 Climate Migrants and New Identities? The Geopolitics of Embracing or Rejecting Mobility. Social and Cultural Geography I7 (4): $533-552$.

Fijian Government Online Portal

20I4 His Excellency Ratu Epeli Nailatikau: Address at State Dinner Hosted by the President and First Lady of Kiribati. Tarawa, Io February. http://www.fiji.gov.fj/Media-Center/Speeches/HIS-EXCELLENCY --ADDRESS-AT-STATE-DINNER-HOSTED-BY-.aspx [accessed $2 \mathrm{I}$ Jan 20I7]

2015 Making Communities the Focus of Climate Change Relocation. Press release, I9 February. http://www.fiji.gov.fj/Media-Center/Press -Releases/MAKING-COMMUNITIES-THE-FOCUS-OF-CLIMATE -CHANGE-REL.aspx [accessed 2I Jan 20I7]

Fiske, Shirley J, Susan A Crate, Carole L Crumley, Kathleen Galvin, Heather Lazrus, Lisa Lucero, Anthony Oliver-Smith, Ben Orlove, Sarah Strauss, and Richard R Wilk

2014 Changing the Atmosphere: Anthropology and Climate Change. Final report of the AAA Global Climate Change Task Force, December. Arlington, va: American Anthropological Association.

Fraenkel, Jon

2015 Melanesia in Review: Issues and Events, 2014: Fiji. The Contemporary Pacific 27:508-5I8.

France, Peter

I969 The Charter of the Land: Custom and Colonization in Fiji. Melbourne: Oxford University Press.

Government of the Republic of Fiji

2012 Republic of Fiji National Climate Change Policy. Suva: Secretariat of the Pacific Community. http://www.sprep.org/attachments/Climate _Change/Fiji-National-Climate-Change-Policy.pdf [accessed 2 I Jan 20I7] 
Hermann, Elfriede

2003 Manifold Identifications within Differentiations: Shapings of Self among the Relocated Banabans of Fiji. Focaal 42:77-88.

2005 Emotions and the Relevance of the Past: Historicity and Ethnicity among the Banabans of Fiji. In Ethnographies of Historicity, edited by Eric Hirsch and Charles Stewart. Special issue of History and Anthropology I6 (3): 275-29I.

20I7 Climate Change and Worries over Land: Articulations in the Atoll State of Kiribati. In Environmental Transformations and Cultural Responses: Ontologies, Discourses, and Practices in Oceania, edited by Eveline Dürr and Arno Pascht, 49-73. New York: Palgrave Macmillan.

Kaplan, Martha

2004 Fiji's Coups: The Politics of Representation and the Representation of Politics. In Globalization and Culture Change in the Pacific Islands, edited by Victoria S Lockwood, 72-85. Upper Saddle River, NJ: Pearson Prentice Hall.

Kempf, Wolfgang

2012 A Promised Land in the Diaspora: Christian Religion, Social Memory, and Identity among Banabans in Fiji. Pacific Studies 35 (I/2): 90-I I 8 .

forthcoming The Diversification of Return: Banaban Homes and Movements in Historical Perspective. In Mobilities of Return: Pacific Perspectives, edited by Helen M Lee and John Taylor. Canberra: ANU Press.

Kempf, Wolfgang, and Elfriede Hermann

2005 Reconfigurations of Place and Ethnicity: Positionings, Performances and Politics of Relocated Banabans in Fiji. Oceania 75 (4):368-386.

2014 Epilogue. Uncertain Futures of Belonging: Consequences of Climate Change and Sea Level Rise in Oceania. In Belonging in Oceania: Movement, Place-Making and Multiple Identifications, edited by Elfriede Hermann, Toon van Meijl, and Wolfgang Kempf, I89-2I3. Oxford: Berghahn.

Klepp, Silja, and Johannes Herbeck

2016 The Politics of Environmental Migration and Climate Justice in the Pacific Region. Journal of Human Rights and the Environment 7 (I): 54-73.

Korauaba, Taberannang

2015 Micronesia in Review: Issues and Events, I July 2013 to 30 June 20I4: Kiribati. The Contemporary Pacific 27:232-238.

Lal, Brij V

1992 Broken Waves: A History of the Fiji Islands in the Twentieth Cen- 
tury. Pacific Islands Monograph Series II. Honolulu: Center for Pacific Islands Studies and University of Hawai'i Press.

2006 Islands of Turmoil: Elections and Politics in Fiji. Canberra: ANU Press.

Lazrus, Heather

2012 Sea Change: Island Communities and Climate Change. Annual Review of Anthropology 4I:28 5-30I.

Leckie, Scott

20I4 Introduction. In Land Solutions for Climate Displacements, edited by Scott Leckie, I-52. London: Routledge.

MacKenzie, Ueantabo N

2004 "The Sun Has Come Down Closer to My Island": People's Perceptions of Climate Change; A Social Assessment Report. Tarawa: Kiribati Adaptation Project.

McAdam, Jane

20I4 Historical Cross-Border Relocations in the Pacific: Lessons for Planned Relocations in the Context of Climate Change. The Journal of Pacific History 49 (3): 30I-327.

McLean, Roger, and Paul Kench

2015 Destruction or Persistence of Coral Atoll Islands in the Face of 2oth and 2 ist Century Sea-level Rise? WIREs Climate Change 6 (5): $445-463$.

Mimura, Nobuo, Leonard Nurse, Roger McLean, John Agard, Lino Briguglio, Penehuro Lefale, Rolph Payet, and Graham Sem

2007 Small Islands. In Climate Change 2007: Impacts, Adaptation and Vulnerability; Contribution of Working Group II to the Fourth Assessment Report of the Intergovernmental Panel on Climate Change, edited by Martin Parry, Osvaldo Canziani, Jean Palutikof, Paul van der Linden, and Clair Hanson, 687-7I6. Cambridge, UK: Cambridge University Press.

Nurse, Leonard, Roger McLean, John Agard, Lino Pascal Briguglio, Virginie Duvat-Magnan, Netatua Pelesikoti, Emma Tompkins, and Arthur Webb

20I4 Small Islands. In Climate Change 20I4: Impacts, Adaptation, and Vulnerability. Part B: Regional Aspects; Contribution of Working Group II to the Fifth Assessment Report of the Intergovernmental Panel on Climate Change, edited by Vicente Barros, Christopher Field, David Jon Dokken, Michael Mastrandrea, Katharine Mach, T Eren Bilir, Monalisa Chatterjee, and others, I6I3-I654. Cambridge, uk: Cambridge University Press.

Office of the President, Republic of Kiribati

2014 Kiribati Buys a Piece of Fiji. Press release, 30 May. http://www.climate .gov.ki/tag/president-anote-tong/ [accessed 2I Jan 20I7] 
Pessar, Patricia R, and Sarah J Mahler

2003 Transnational Migration: Bringing Gender In. International Migration Review 37 (3): 8 I 2-846.

Radio New Zealand

2009 Fiji Considers Accepting Climate Change Refugees. I I December. http://www.radionz.co.nz/international/pacific-news/I 877 I I/fiji -considers-accepting-climate-change-refugees [accessed I9 March 20I7]

Rapport, Nigel, and Andrew Dawson

I998 Home and Movement: A Polemic. In Migrants of Identity: Perceptions of Home in a World of Movement, edited by Nigel Rapport and Andrew Dawson, I9-38. Oxford: Berg.

Rawalai, Luke

20I4 Climate Change Affects Villages. Fiji Times, I7 January. http://www

Salazar, Noel B .fijitimes.com/story.aspx?id=257I64 [accessed 2I Jan 20I7]

20I I The Power of Imagination in Transnational Mobilities. Identities: Global Studies in Culture and Power I 8 (6): 576-598.

Silverman, Martin G

I97I Disconcerting Issue: Meaning and Struggle in a Resettled Pacific Community. Chicago: University of Chicago Press.

Teaiwa, Katerina Martina

2015 Consuming Ocean Island: Stories of People and Phosphate from Banaba. Bloomington: Indiana University Press.

Teaiwa, Teresia K

I997 Rabi and Kioa: Peripheral Minority Communities in Fiji. In Fiji in Transition, edited by Brij V Lal and Tomasi R Vakatora, I3O-I 52. Suva: The University of the South Pacific.

Teuatabo, Nakibae

2002 Vulnerability of Kiribati to Climate Change and Sea-Level Rise: Scientific Information Needs to Be Comprehensive, and Unfettered of Advocacy. In Proceedings of the APN Workshop on Ethnographic Perspectives on Resilience to Climate Variability in Pacific Island Countries, edited by Jon Barnett and Mark Busse, 67-70. Christchurch: Macmillan Brown Centre for Pacific Studies, University of Canterbury.

Tito, Keina, Tebaubwebwe Tiata, Baie Teanako, Ueantabo Fakaofo, and Arobati Tautau

I984 Tradition: Ancient Gilbertese Society. In Kiribati: Aspects of History, by Sister Alaima Talu and others, I 2-28. Suva: Institute of Pacific Studies and Extension Services, University of the South Pacific; 
Tarawa: Kiribati Ministry of Education, Training and Culture. First

Tomlinson, Matt published in 1979 .

2009 In God's Image: The Metaculture of Fijian Christianity. Berkeley: University of California Press.

Tong, Anote

2OI4 Statement by HE President Anote Tong. Third International Conference on sids, Apia, Sāmoa, 2 September. Available online at https://sustainabledevelopment.un.org/content/documents/ I I60945 5 Kiribati.pdf [accessed 20 Jan 20I7]

Uan, Linda, and John Anderson

20I4 Climate Displacement and Kiribati: Notes from the Frontline. In Land Solutions for Climate Displacements, edited by Scott Leckie, 228-250. London: Routledge.

Uriam, Kambati K

I995 In Their Own Words: History and Society in Gilbertese Oral Tradition. Canberra: The Journal of Pacific History.

\section{Abstract}

In this article we concentrate on the discursive links between climate change, migration, land, and imagined futures. We argue that the large tract of freehold land purchased by Kiribati's government in Fiji has led citizens in both countries to develop imaginings of migration, which we interpret as building blocks for a cultural construct of the future, in anticipation of projected hazards resulting from climate change and sea level rise. We show that, contrary to official pronouncements that the land had been acquired for reasons of food security, many citizens of Kiribati and Fiji associated the purchase with the option of a future relocation. Thus I-Kiribati have taken to perceiving this property in terms of their concept of land, hoping that, in the event of an existential threat, this new land will allow them to preserve culture, nation, and identity over the long term. Citizens of Fiji, too, rely on their concept of land, as when they see that survival for I-Kiribati will only be possible if they can ground it in a territory of their own. Moreover, the governments of Kiribati and Fiji both engage in a politics of hope that contributed to imaginings of migration. We conclude that the emerging discourses on migration related to the land purchase were fostered by cultural conceptions of land as well as the climate policies of the two Pacific Island states.

KEYWORDS: climate change, migration, imagination, hope, future, relocation, identity 